\title{
Molecular Identification of an Invasive Sarotherodon Species from the Atchakpa Freshwater Reservoir (Ouémé River Basin, Benin) and Comparison within S. melanotheron Using COI Markers
}

\author{
Rodrigue Orobiyi Edéya Pèlèbè ${ }^{1,2, *(\mathbb{D})}$, Ibrahim Imorou Toko ${ }^{1}\left(\mathbb{D}\right.$, Erik Verheyen ${ }^{3,4}(\mathbb{D}$ and \\ Maarten Van Steenberge ${ }^{3}$ iD \\ 1 Research Laboratory in Aquaculture and Aquatic Ecotoxicology (LaRAEAq), Faculty of Agronomy (FA), \\ University of Parakou (UP), P.O. Box 61 Parakou-University, Parakou, Benin; iimorou_toko@hotmail.com \\ 2 World Bank Africa Centre of Excellence in Coastal Resilience (ACECoR), University of Cape Coast (UCC), \\ Ground Floor C. A. Ackah Lecture Theatre Complex, Cape Coast, Ghana \\ 3 Operational Directorate (OD) Taxonomy and Phylogeny, Royal Belgian Institute for Natural Sciences (RBINS), \\ Vautierstraat 29, 1000 Brussels, Belgium; everheyen@naturalsciences.be (E.V.); \\ mvansteenberge@naturalsciences.be (M.V.S.) \\ 4 Department Biology, Evolutionary Ecology, University of Antwerp, Universiteitsplein 1, \\ 2610 Antwerpen, Belgium \\ * Correspondence: peleberodrigue@yahoo.fr or rodrigue.pelebe@ucc.edu.gh; \\ Tel.: +229-96-97-57-62 or +233-(0)-055-242-8692
}

Citation: Pèlèbè, R.O.E.; Imorou Toko, I.; Verheyen, E.; Van Steenberge, M. Molecular Identification of an Invasive Sarotherodon Species from the Atchakpa Freshwater Reservoir (Ouémé River Basin, Benin) and Comparison within S. melanotheron Using COI Markers. Diversity 2021, 13, 297. https://doi.org/10.3390/ d13070297

Academic Editors: Stephan Koblmüller and Michael Wink

Received: 14 May 2021

Accepted: 29 June 2021

Published: 30 June 2021

Publisher's Note: MDPI stays neutral with regard to jurisdictional claims in published maps and institutional affiliations.

Copyright: (c) 2021 by the authors. Licensee MDPI, Basel, Switzerland. This article is an open access article distributed under the terms and conditions of the Creative Commons Attribution (CC BY) license (https:// creativecommons.org/licenses/by/ $4.0 /)$.
Abstract: The Atchakpa freshwater reservoir (Ouémé Basin, Benin) was found to harbour an unexpected population of a cichlid species that was presumed to be Sarotherodon melanotheron. This species became dominant in the reservoir and became the main fisheries target species. We applied DNA barcoding to identify this population. Besides specimens from the reservoir, we also sequenced $S$. melanotheron from its native range in Benin at the lower Ouémé and Sô Rivers, and from Lake Nokoué, and Porto-Novo Lagoon. High sequence similarity indicated that all specimens were conspecific. Hence, we cannot exclude that a natural range extension led to the presence of the species in the reservoir. A comparison with sequences from NCBI GenBank confirmed that all samples belonged to the subspecies S. m. melanotheron, which is native to Benin. This comparison also showed that this subspecies was previously introduced in the Philippines. We call for further studies to investigate the socioeconomic, ecological and environmental impacts of the species in the Atchakpa reservoir.

Keywords: cytochrome c oxidase subunit I; black-chin tilapia; DNA barcoding; Savè; species introductions

\section{Introduction}

The black-chin tilapia, Sarotherodon melanotheron (Rüppell, 1852), is an estuarine species endemic to West and Central Africa [1-3] that is well known from the brackish waters of southern Benin. In the Ouémé River basin, its limit of frequent occurrence is the village of Agonlin-Lowé (Commune of Adjohoun, department of Ouémé) [4]. This locality is considered the boundary between the continental and the coastal domains in Benin [4] (Figure 1). However, rare specimens of $S$. melanotheron have been found upstream of Agonlin-Lowé in southern Benin (rare occurrences at the Ouémé River at Toué, Commune of Covè, department of Zou [4], at the Hlan River at Lokoli, Commune of Zogbodomey, department of Zou [5] and in the Lake Hlan at Kpomè, Commune of Toffo, department of Atlantic [6]) (Figure 1).

A large population of presumed S. melanotheron was discovered prior to 2001 in the Atchakpa freshwater reservoir (SUCOBE dam built in 1982), which is located in central Benin, about $230 \mathrm{~km}$ north of Agonlin-Lowé [4,7]. This population, which was only morphologically identified, thrived in the landlocked reservoir. Despite its proximity to 
the main course of the Ouémé River, the reservoir has no direct connection with the river (Figure 2) although, during severe dry seasons, seasonal contact with river water can occur through pumping. S. melanotheron is quasi-inexistent at the Ouémé River near the reservoir as only one individual was captured during three years of intensive sampling from 1998 to 2001 [4]. Moreover, the Atchakpa fisheries management committee has, in recent years, not reported any catches of this species in the Ouémé River near the reservoir. If the morphological identifications of $[4,7]$ are correct, this population is isolated from the rest of its natural geographic distribution in Benin.

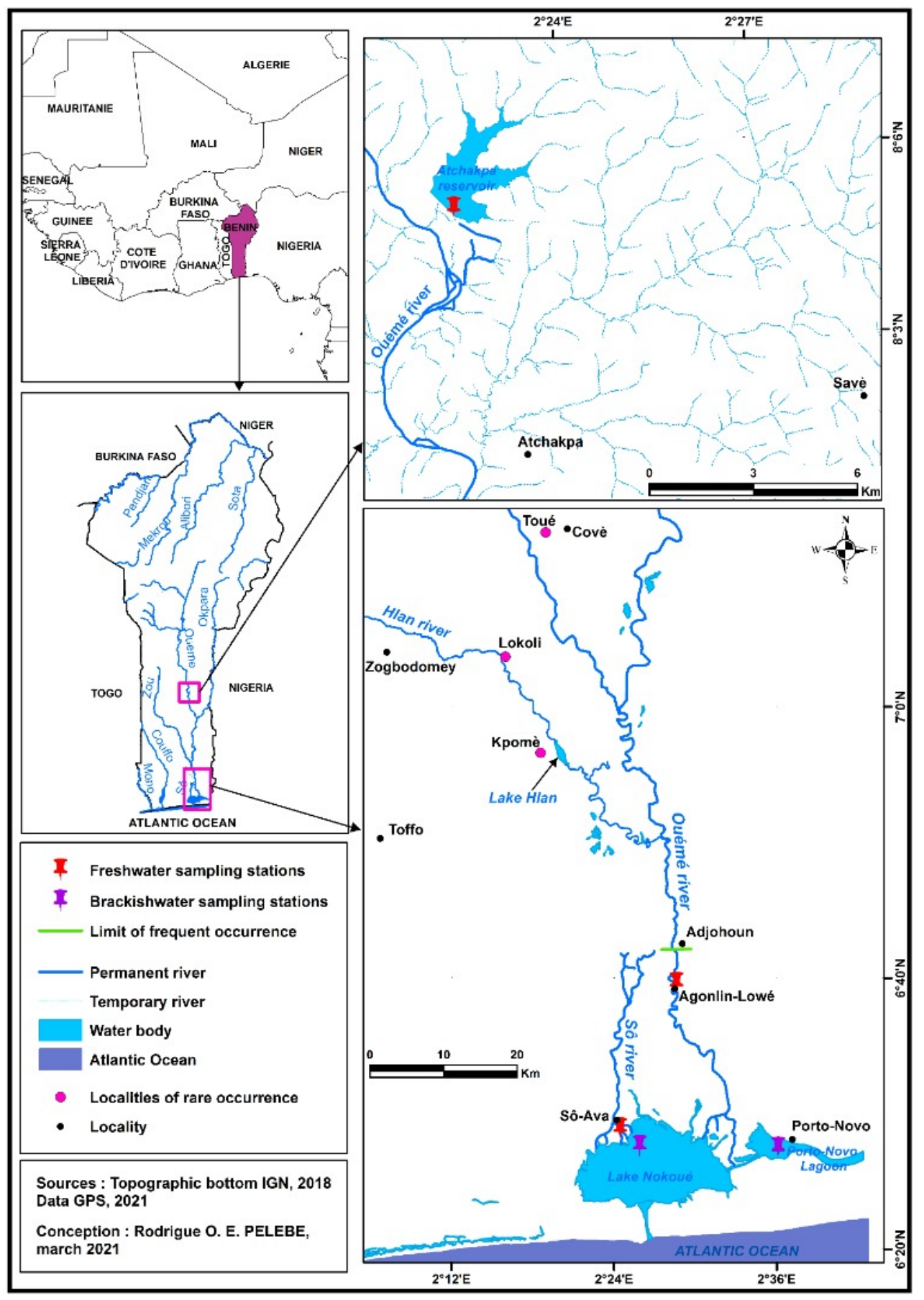

Figure 1. Hydrographic map of Benin showing the Ouémé River basin, with the location of the Atchakpa reservoir, the sampling stations, the limit of frequent occurrence and the localities of rare occurrences of S. melanotheron. 


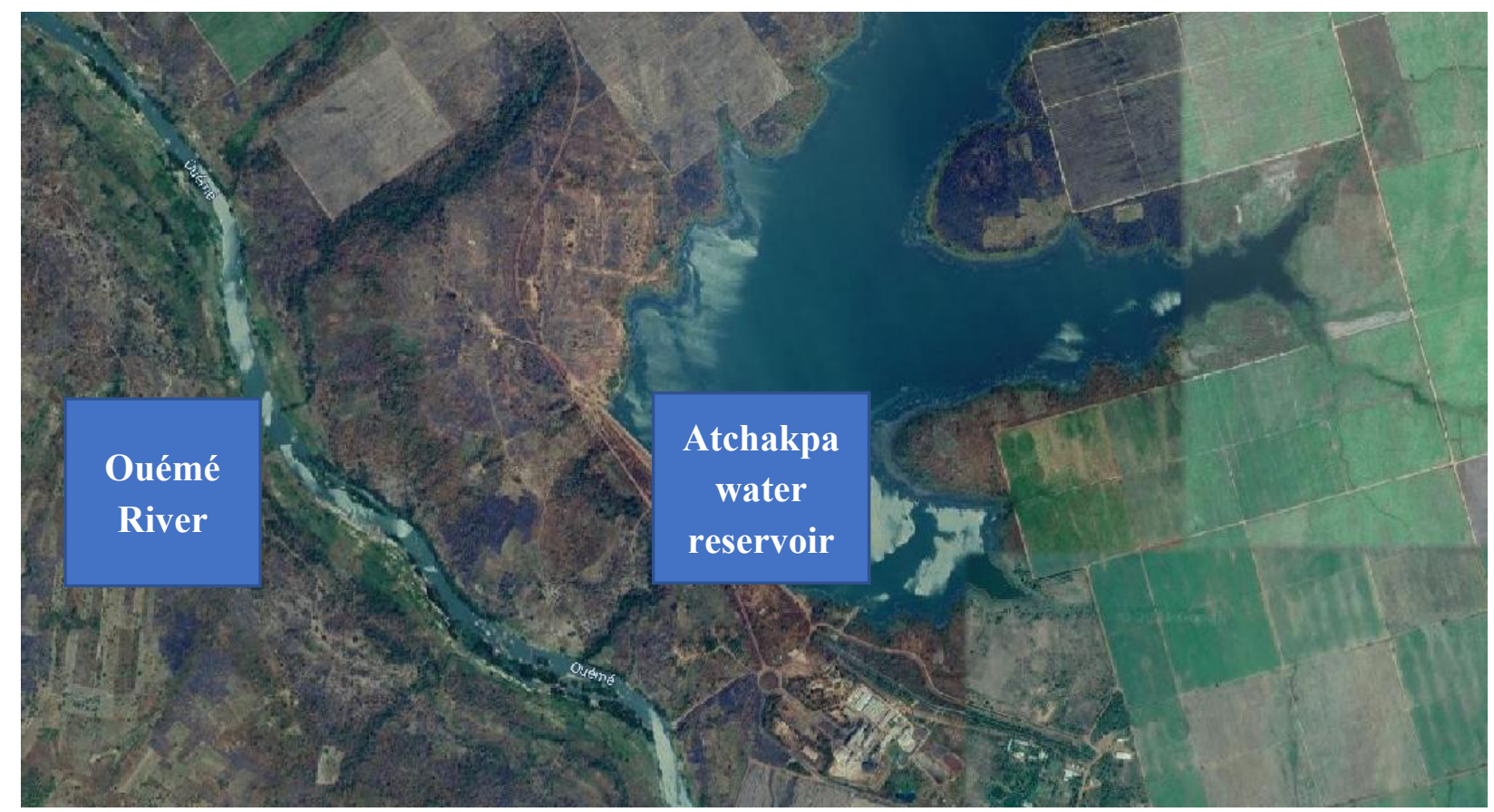

Figure 2. Satellite image highlighting the absence of direct communication between the main course of the Ouémé River and the Atchakpa freshwater reservoir (source: Google maps).

The fisheries in the Atchakpa reservoir ensure the supply of fish for the city of Savè. Currently, the population morphologically identified as S. melanotheron dominates the catches of local fishermen in terms of abundance. According to [8], S. melanotheron represents $72 \%$ (numerical abundance) of the fish caught at the Atchakpa reservoir and sold at the fish market in Savè. It thus surpasses the Nile tilapia Oreochromis niloticus (Linnaeus, 1758), which was introduced into the reservoir through aquaculture (direct restocking in 1985 and cage culture in 2014). Nile tilapia is currently rare whereas it was very common in the 1990s.

Sarotherodon melanotheron is known to be invasive, i.e., it has the potential to spread widely, reproduce rapidly and persist in a new environment with a large range of impacts $[9,10]$. Knowing the correct identity of an invasive species is an important prerequisite for its efficient management. The identification of invasive cichlids using only metric and meristic parameters requires caution due to their mega-diversity and the widespread introduction of alien species [11,12]. Therefore, molecular evidence is often required to provide additional verification. Hence, we chose to, for the first time in Beninese fisheries, apply a DNA barcoding approach. DNA barcoding is a molecular technique for fast and accurate determination of species identity [13]. In animals, DNA barcoding is usually performed by sequencing a fragment of the mitochondrial cytochrome c oxidase subunit I gene, COI (barcode), of the specimen under investigation and its comparison with a reference library of barcode sequences [14,15].

Sarotherodon melanotheron contains substantial intra-specific geographic structure, with three subspecies: S. melanotheron melanotheron Ruppell, 1852, S. m. heudelotii (Dumeril, 1859), S. m. leonensis (Thys van den Audenaerde, 1971) currently recognised [16]. The latter subspecies contains the synonym S. m. paludinosus (Trewavas, 1983) [16,17]. Additionally, S. melanotheron is highly similar to its sister species S. nigripinnis (Guichenot, 1861). Although the subspecies are difficult to distinguish on morphological grounds, they can be delineated with mitochondrial markers [16,17]. A molecular approach could hence allow us to confirm the subspecific nature of the Sarotherodon population, along with the implied geographic affinities. According to the management committee of the Atchakpa fisheries, no species of Sarotherodon has been stocked in the reservoir. However, it remains to be 
verified whether the population in the reservoir belongs to the nearest strain from the Ouémé, or whether it has been introduced from elsewhere.

Tilapia species, including S. melanotheron, have been extensively introduced outside of their native range and often established feral populations. This also holds for S. melanotheron, which is, among others, found in the Philippines [9,18], Florida [19] and Hawaii [20]. As most tilapia introductions have been poorly documented, the correct identity of feral populations often remains unknown. DNA barcoding can aid in discovering the origin of introduced populations. However, as African freshwater fishes are underrepresented in barcoding libraries [21], there is a need to barcode specimens from the species' native range.

The aims of this study are twofold: (i) the molecular identification of the invasive cichlid species from the Atchakpa reservoir and (ii) constructing a databank of DNA barcodes of $S$. melanotheron from its range in the Ouémé River in Benin, and comparing these sequences with previously published sequences of the same species in GenBank.

\section{Materials and Methods}

Sampling took place at five sites in the Ouémé River in Benin (Figure 1). Besides the Atchakpa reservoir, we sampled in two brackish waters: Lake Nokoué and PortoNovo Lagoon, and two freshwaters: Agonlin-Lowé (Ouémé River) and Sô-Ava (Sô River), where S. melanotheron is native. Sampling took place in January 2020 and specimens were identified using the identification key of [22]. At each site, twenty-two specimens of $S$. melanotheron were collected with the help of local fishermen. We also sampled at the localities of rare occurrence (Toué, Lokoli and Kpomè, see Figure 1), but failed to collect any specimens of $S$. melanotheron there.

Caudal fin clips were sampled and put into $1.5 \mathrm{~mL}$ sterile Eppendorf tubes containing pure ethanol as a preservation medium. Four specimens per site were fixed in formalin and deposited at the Royal Belgian Institute for Natural Sciences (RBINS) under collection numbers: Atchakpa water reservoir (25907, 25908, 25909, and 25910), Sô-Ava (Sô River) (25923, 25924, 25925, and 25926), Agonlin-Lowé (Ouémé River) (25911, 25912, 25913, and 25914), Porto-Novo Lagoon (25915, 25916, 25917, and 25918) and Lake Nokoué (25919, 25920,25921 , and 25922). Fin clips were stored at $-20^{\circ} \mathrm{C}$ at the Molecular Systematics Laboratory of the RBINS.

Total genomic DNA was extracted using NucleoSpin ${ }^{\circledR}$ Tissue Kit following the instructions of the manufacturer (Macherey-Nagel, Düren, Germany). The mitochondrial COI gene region for each of five specimens per locality, except only four for Lake Nokoué, was amplified by polymerase chain reaction (PCR) using the 'Fish Cocktail': an M13 tailed primer combination of VF2_t1, FishF2_t1, FishR2_t1 and VR1d_t1 [23]. A standard $25.2 \mu \mathrm{L}$ PCR mix consisted of $2.5 \mu \mathrm{L}$ PCR buffer $(10 \times) ; 2.5 \mu \mathrm{L} \mathrm{dNTP}(2 \mathrm{mM}) ; 1.25 \mu \mathrm{L}$ 'Fish Cocktail' $(2 \mu \mathrm{M}) ; 0.2 \mu \mathrm{L}$ Taq DNA Polymerase ( 5 units per $\mu \mathrm{L}) ; 16.75 \mu \mathrm{L} \mathrm{mQ}-\mathrm{H} 2 \mathrm{O}$ and $2.0 \mu \mathrm{L}$ of the extracted DNA sample. The PCR profile was $3 \mathrm{~min}$ at $94^{\circ} \mathrm{C}$, followed by 35 cycles of $40 \mathrm{~s}$ at $94{ }^{\circ} \mathrm{C}, 40 \mathrm{~s}$ at $52{ }^{\circ} \mathrm{C}$, and $1 \mathrm{~min}$ at $72{ }^{\circ} \mathrm{C}$, plus a final extension of $10 \mathrm{~min}$ at $72{ }^{\circ} \mathrm{C}$. Amplicons were examined with $1 \%$ agarose gel electrophoresis. Products were purified with ExoSAP-IT ${ }^{\mathrm{TM}}$ PCR Product Cleanup Reagent and bidirectionally sequenced using BigDye Terminator v.3.1. Fragments were analysed on an ABI 3130 capillary sequencer. Forward and reverse sequences were edited, used to build consensus sequences, visually checked in CodonCode Aligner 5.1.4 (CodonCode Corporation) and aligned in MEGA 5.2 using Muscle Alignment [24]. Sequences were compared to the database of NCBI GenBank using nucleotide BLAST (Basic Local Alignment Search Tool). Based on earlier studies, the sequence similarity of at least $98 \%$ was used to separate conspecific from heterospecifics $[25,26]$.

We downloaded all 39 COI sequences of S. melanotheron available on GenBank (Table 1) and analysed them together with our 17 newly generated sequences (Dataset S1). We constructed a minimum spanning network using PopART [27]. Additionally, a neighbourjoining (NJ) tree [28] based on Kimura-2-Parameter (K2P) distances and using S. galileaus 
(KY84676) as an outgroup was constructed using MEGA 5.2. Nodal support was assessed with bootstrapping, using 1000 replicates. Kimura-2-Parameter (K2P) distances were calculated using unique haplotypes, obtained using FaBox 1.5.

Table 1. Information on newly generated COI sequences of S. melanotheron and those retrieved from GenBank.

\begin{tabular}{|c|c|c|c|c|c|c|}
\hline Aquatic Ecosystems & $\begin{array}{l}\text { Number of } \\
\text { COI } \\
\text { Sequences }\end{array}$ & $\begin{array}{l}\text { Accessions } \\
\text { Numbers } \\
\text { GenBank }\end{array}$ & $\begin{array}{l}\text { Codes for Our } \\
\text { Samples }\end{array}$ & Country & Status & Reference \\
\hline Atchakpa reservoir & 05 & $\begin{array}{l}\text { MT180099 (1) } \\
\text { MT180100 (1) } \\
\text { MT180101 (1) } \\
\text { MT180102 (2) }\end{array}$ & $\begin{array}{c}\text { ATCH2 } \\
\text { ATCH3 } \\
\text { ATCH4 } \\
\text { ATCH5 and } \\
\text { ATCHF-H01 }\end{array}$ & Benin & & This study \\
\hline $\begin{array}{l}\text { Agonlin-Lowé } \\
\text { (Ouémé River) }\end{array}$ & 04 & $\begin{array}{l}\text { MT180103 (1) } \\
\text { MT180106 (3) }\end{array}$ & $\begin{array}{c}\text { FOUE3 } \\
\text { FOUE2, } \\
\text { FOUE4F-H03 and } \\
\text { FOUE5F-G03 }\end{array}$ & Benin & Native & This study \\
\hline $\begin{array}{l}\text { Sô-Ava } \\
\text { (Sô River) }\end{array}$ & 01 & MT180104 (1) & RISO1 & Benin & Native & This study \\
\hline Porto-Novo Lagoon & 04 & MT180102 (4) & $\begin{array}{l}\text { LAPO2F-E03, } \\
\text { LAPO1F-F03, } \\
\text { LAPO3F-D03 and } \\
\text { LAPO4F-C03 }\end{array}$ & Benin & Native & This study \\
\hline Lake Nokoué & 03 & $\begin{array}{l}\text { MT180107 (1) } \\
\text { MT180108 (2) }\end{array}$ & $\begin{array}{c}\text { LANO2 } \\
\text { LANO3 and } \\
\text { LANO1F-A03 }\end{array}$ & Benin & Native & This study \\
\hline Manila Bay Lake & 04 & $\begin{array}{l}\text { KM212014- } \\
\text { KM212016; } \\
\text { KM212018 }\end{array}$ & - & Philippines & Feral & [9] \\
\hline Taal Lake & 05 & $\begin{array}{l}\text { HQ654753- } \\
\text { HQ654757 }\end{array}$ & - & Philippines & Feral & [18] \\
\hline Laguna de Bay Lake & 05 & $\begin{array}{l}\text { HQ682721- } \\
\text { HQ682725 }\end{array}$ & - & Philippines & Feral & [29] \\
\hline Not specified & 01 & MT666031 & - & Hawaii & Feral & Unpublished \\
\hline Odooba River & 02 & $\begin{array}{l}\text { KX231781- } \\
\text { KX231782 }\end{array}$ & - & Nigeria & Native & [30] \\
\hline $\begin{array}{l}\text { Banc d'Arguin } \\
\text { National Park } \\
\text { (PNBA) }\end{array}$ & 16 & $\begin{array}{c}\text { KJ938183- } \\
\text { KJ938191; } \\
\text { KJ938208- KJ938214 }\end{array}$ & - & Mauritania & Native & [31] \\
\hline Guiers Lake & 04 & KJ938215-KJ938218 & - & Senegal & Native & [31] \\
\hline $\begin{array}{c}\text { State Zhongji } \\
\text { Tilapia Farm, Hebei } \\
\text { Province }\end{array}$ & 02 & $\begin{array}{c}\text { NC_015611 } \\
\text { JF894132 }\end{array}$ & - & China & Farmed & [32] \\
\hline
\end{tabular}

In the column "Accessions numbers GenBank", the accession number in bold was mislabelled as S. melanotheron but instead belongs to Coptodon guineensis. Hence, it was not included in the phylogenetic analysis; the accession number in italics was shorter (313 bp vs. $443 \mathrm{bp}$ ) and was only directly compared to other sequences; numbers in brackets denote how many specimens are contained in a single sequence.

\section{Results}

\subsection{Molecular Identification of the Specimens}

A total of 22 partial mitochondrial COI sequences (five for each of the following ecosystems: Atchakpa water reservoir, Ouémé River and Porto-Novo Lagoon, and three and four for Lake Nokoué and Sô River, respectively) were successfully obtained from 24 samples. For 17 of these, a complete length of 443 bp was obtained (Table 1). The dataset 
consisted of three unique haplotypes that differed by only one or two nucleotides. The first contained 14 samples from all locations. The other haplotypes contained two (one from the Atchakpa Reservoir, one from Porto Novo Lagoon), and one sample (from Agonlin-Lowé). BLAST revealed a similarity of $99.8-100 \%$ with sequences from Sarotherodon melanotheron deposited by [18] (HQ654754 and HQ654753) and [29] (HQ682724 and HQ682721). This confirmed the identification of our samples as $S$. melanotheron.

\subsection{Comparison with Available Sequences of S. melanotheron}

Thirty-nine COI sequences identified as S. melanotheron were retrieved from NCBI GenBank (Table 1). One of these (KJ938191) was considered mislabelled and was removed from further analyses. This sequence was coded as Coptodon guineensis in [31]. The COI sequence of this specimen matched that of $C$. guineensis and differed by at least $15 \%$ from all S. melanotheron sequences. We constructed a minimum spanning network (Figure 3 ) and an NJ tree (Figure 4) with all available sequences of length $443 \mathrm{bp}$. This revealed three clusters in S. melanotheron. The first cluster included all sequences from Benin (present study), as well as sequences from Nigeria, and some sequences from the Philippines (Taal Lake and Laguna de Bay). The sequence from Hawaii was, although shorter, identical to those of the main haplotype of cluster 1 (not shown). The second, central, cluster contained sequences from Mauritania and Senegal. The third cluster contained the remaining sequences from the Philippines as well as those from China. Maximum within-cluster divergence ranged from 0.23 to $0.45 \%$, minimum between cluster divergence ranged from $0.68 \%$ ( 1 vs. 2 ), $0.91 \%(2$ vs. 3$)$ and $1.14 \%$ (1 vs. 3$)$.
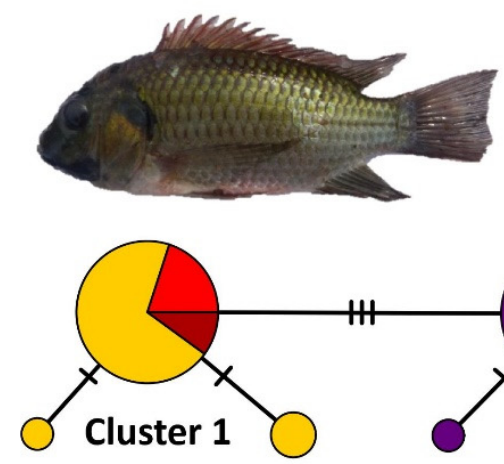

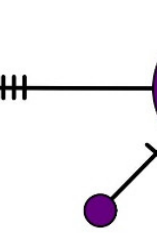

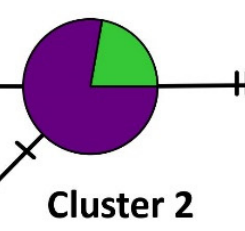

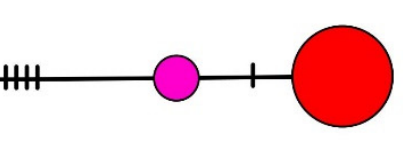

Cluster 3

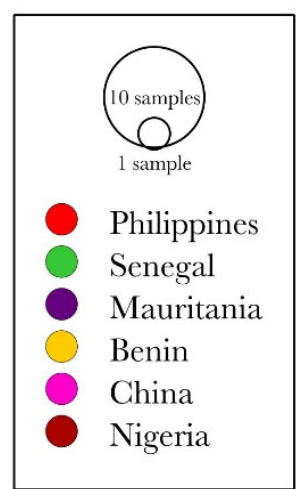

Figure 3. Minimum spanning network constructed from COI sequences of S. melanotheron obtained in our study and from GenBank. Colours denote countries where specimens were sampled, node size the number of sequences in a haplotype. The photograph represents a specimen of S. melanotheron from the Atchakpa reservoir (Photo credit: R.O.E. Pèlèbè). 


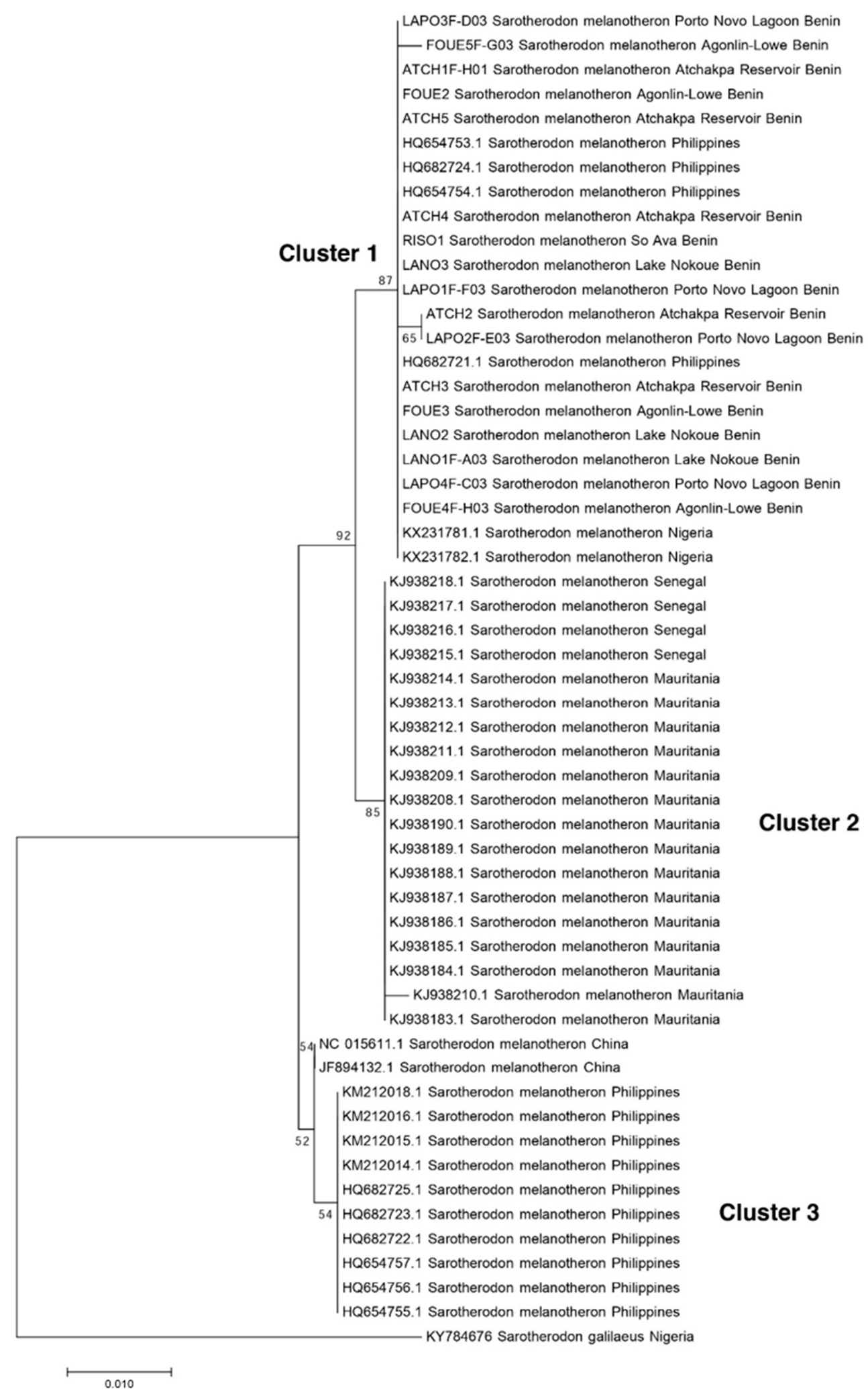

Figure 4. NJ tree constructed from the COI sequences of S. melanotheron obtained in our study and from GenBank.

\section{Discussion}

In this study, the use of DNA barcoding allowed us to identify the cichlid population that became landlocked in the Atchakpa freshwater reservoir as Sarotherodon melanotheron. Although we could not unambiguously determine the origin of the population, we found 
no indication that the population in the Atchakpa reservoir belongs to a different strain than the rest of the specimens from Benin. Hence, it could have arrived in the reservoir naturally, or via pumping of river water into the reservoir. The former explanation raises doubt on whether the reservoir has always remained physically separated from the river. The mechanisms by which $S$. melanotheron replaced $O$. niloticus remain unknown. As $S$. melanotheron has a broad ecological tolerance, its success could be linked to environmental parameters in the reservoir. This, however, remains to be investigated.

The three clusters in S. melanotheron found using COI correspond to those found by [33] using the mitochondrial control region, which corresponds to three of the four subspecies. These are S. melanotheron heudelotti found from the coasts of Mauritania to Guinea (cluster 2), S. m. leonensis occurring from Sierra Leone to western Liberia (most likely cluster 3), and S. m. melanotheron known from Ivory Coast to Nigeria (cluster 1) [16,17,30,31,33]. Although we lack sequences from native populations in cluster 3 , it can be assumed that this cluster corresponds to $S$. $m$. leonensis. All sequences from Benin fell in cluster 1, which corresponds to $S$. melanotheron melanotheron. The comparison of COI sequences revealed interesting patterns about the introduced populations of $S$. melanotheron. The presence of a cluster 1 haplotype in the specimen from Hawaii is in accordance with the recorded introduction of the species on the islands in 1962 [20]. This strain derived via Europe and New York [34] from the area of the subspecies S. m. melanotheron in Africa [35]. As the farmed population in the State Zhongji Tilapia Farm in China [36] has a cluster 3 haplotype, it most likely stems from the range of $S$. $m$. leonensis. Finally, the populations present in the Philippines contain haplotypes of both clusters 1 and 3, which suggests that at least two introductions took place on the islands.

Although we were able to identify the invasive population in the Atchakpa freshwater reservoir, further studies on its socioeconomic, ecological and environmental impacts should be done. This study represents the first successful usage of DNA barcoding in Beninese fisheries research. Its success highlights that investigations must be undertaken to assembly a national fish DNA barcodes reference library in Benin, useful for reliable monitoring and effective management and conservation of fish biodiversity.

Supplementary Materials: The following is available online at https:/ / www.mdpi.com/article/10 .3390/d13070297/s1, Dataset S1: COI sequences used for constructing the NJ phylogenetic tree.

Author Contributions: Conceptualization, R.O.E.P., M.V.S. and E.V.; methodology, R.O.E.P., M.V.S. and E.V.; formal analysis, R.O.E.P. and M.V.S.; data curation, R.O.E.P., and M.V.S.; investigation, R.O.E.P. and M.V.S.; writing-original draft preparation, R.O.E.P.; writing-review and editing, R.O.E.P., M.V.S. and E.V.; visualization, R.O.E.P.; supervision, I.I.T., M.V.S. and E.V.; funding acquisition, R.O.E.P. All authors have read and agreed to the published version of the manuscript.

Funding: This research was funded by the Belgian National Focal Point to the Global Taxonomy Initiative (GTI) that runs under the Capacities for Biodiversity and Sustainable Development (CEBioS) programme with financial support from the Belgian Directorate-General for Development Cooperation (DGD).

Institutional Review Board Statement: Not applicable.

Informed Consent Statement: Not applicable.

Data Availability Statement: The data used in this study are openly available in NCBI GenBank (https:/ / www.ncbi.nlm.nih.gov/nuccore/?term=PELEBE) and the dataset on COI sequences is in the Supplementary Materials.

Acknowledgments: We would like to thank Heleen Maetens and Charlotte Willems for their precious help in the lab during the training internship for taxonomy capacity building of R.O.E.P in Belgium, Olivier Pauwels for curatorial services, and Guillaume Koussovi for his assistance during the sampling of fishes in Benin. The first author acknowledges the contribution of the World Bank Africa Centre of Excellence in Coastal Resilience, University of Cape Coast, Ghana for providing him with a good work environment as postdoctoral fellow in fisheries sciences, which was favourable to the finalization of this article. 
Conflicts of Interest: The authors declare no conflict of interest.

\section{References}

1. Trewavas, E.; Teugels, G.G. Sarotherodon. In Check-List of the Freshwater Fishes of Africa (CLOFFA); Daget, J., Gosse, J.-P., Teugels, G.G., Van Den Audenaerde, D.F.E.T., Eds.; Royal Museum for Central Africa: Tervuren, Belgium, 1991; pp. $425-437$.

2. Pauly, D. The biology, fishery and potential for aquaculture of Tilapia melanotheron in a small West African lagoon. Aquaculture 1976, 7, 33-49. [CrossRef]

3. Adepo-Gourene, B.; Gourene, G. Différentiation morphologique des populations naturelles d'une sous espèce de tilapia Sarotherodon melanotheron melanotheron Rüppell, 1852 (Teleostei; Cichlidae) de Côte d'Ivoire. Sci. Nat. 2008, 5, 15-27.

4. Laleye, P.; Chikou, A.; Philippart, J.-C.; Teugels, G.; Vandewalle, P. Etude de la diversité ichtyologique du bassin du fleuve Ouémé au Bénin (Afrique de l'ouest). Cybium 2004, 228, 329-339.

5. Montchowui, E.; Niyonkuru, C.; Ahouansou Montcho, S.; Chikou, A.; Laleye, P. L'ichtyofaune de la rivière Hlan au Bénin (Afrique de l'Ouest). Cybium 2007, 31, 173-176.

6. Montchowui, E.; Chikou, A.; Kogbeto, M.-J.; Laleye, P. Biodiversité et structure des communautés de poissons du lac Hlan au Bénin. Int. J. Biol. Chem. Sci. 2008, 2, 196-206. [CrossRef]

7. Fagnon, S.M.; Chikou, A.; Youssao, I.; Laleye, P. Caractérisation morphologique des populations de Sarotherodon melanotheron (Pisces, Cichlidae) en eaux douces et saumâtres au Sud Bénin. Int. J. Biol. Chem. Sci. 2013, 7, 619-630. [CrossRef]

8. Pèlèbè, E.O.R.; Dohounkpan, G.A.; Agbohessi, T.P.; Imorou Toko, I.; Hounhoedo, A.O.; Lederoun, D. Inventaire partiel des espèces de poisson et évaluation du degré de fraîcheur de Sarotherodon melanotheron vendu au marché des produits de pêche de la commune de Savè (Bénin). Rev. Togol. Sci. 2016, 10, 187-198.

9. Ordoñez, J.; Asis, A.; Catacutan, B.; Pena, J.D.; Santos, M. First report on the occurrence of invasive black-chin tilapia Sarotherodon melanotheron (Ruppell, 1852) in Manila Bay and of Mayan cichlid Cichlasoma urophthalmus (Gunther, 1862) in the Philippines. Bioinvasions Rec. 2015, 4, 115-124. [CrossRef]

10. Cassemiro, F.A.S.; Bailly, D.; Da Graça, W.J.; Agostinho, A.A. The invasive potential of tilapias (Osteichthyes, Cichlidae) in the Americas. Hydrobiologia 2017, 817, 133-154. [CrossRef]

11. Nico, L. Discovery of the invasive Mayan Cichlid fish "Cichlasoma" urophthalmus (Günther 1862) in Thailand, with comments on other introductions and potential impacts. Aquat. Invasions 2007, 2, 197-214. [CrossRef]

12. Miller, R.R.; Minckley, W.L.; Norris, S.M. Freshwater Fishes of Mexico; University of Chicago Press: Chicago, IL, USA, 2005.

13. Trivedi, S.; Aloufi, A.A.; Ansari, A.A.; Ghosh, S.K. Role of DNA barcoding in marine biodiversity assessment and conservation: An update. Saudi J. Biol. Sci. 2016, 23, 161-171. [CrossRef]

14. Hebert, P.D.N.; Cywinska, A.; Ball, S.L.; deWaard, J.R. Biological identifications through DNA barcodes. Proc. Biol. Sci. 2003, 270, 313-321. [CrossRef] [PubMed]

15. Hebert, P.D.; Ratnasingham, S.; De Waard, J.R. Barcoding animal life: Cytochrome c oxidase subunit 1 divergences among closely related species. Proc. R. Soc. B Boil. Sci. 2003, 270, S96-S99. [CrossRef]

16. Falk, T.M.; Teugels, G.G.; Abban, E.K. Revision and biogeographical analysis of the black-chinned tilapia Sarotherodon melanotheron (Teleostei, Cichlidae): Results of morphometric, allozyme, globin chain and mtDNA studies. J. Nat. Hist. 2003, 37, 2191-2212. [CrossRef]

17. Falk, T.M.; Teugels, G.G.; Abban, E.K.; Villwock, W.; Renwrantz, L. Morphometric and allozyme variation in the black-chinned tilapiaSarotherodon melanotheron (Perciformes, Cichlidae), with a revision of the subspecies complex. J. Nat. Hist. 2000, 34, 1849-1863. [CrossRef]

18. Aquilino, S.V.L.; Tango, J.M.; Fontanilla, I.K.C.; Pagulayan, R.C.; Basiao, Z.U.; Ong, P.S.; Quilang, J.P. DNA barcoding of the ichthyofauna of Taal Lake, Philippines. Mol. Ecol. Resour. 2011, 11, 612-619. [CrossRef]

19. Wohlfarth, G.W.; Hulata, G. Applied Genetics of Tilapias, 2nd ed.; International Center for Living Aquatic Resources Management (ICLARM): Manila, Philippines, 1983.

20. Randall, J.E. Introductions of marine fishes to the Hawaiian Islands. Bull. Mar. Sci. 1987, 41, 490-502.

21. Porter, T.M.; Hajibabaei, M. Over 2.5 million COI sequences in GenBank and growing. PLoS ONE 2018, 13, e0200177. [CrossRef] [PubMed]

22. Paugy, D.; Leveque, C.; Teugels, G.G. The Fresh and Brackish Water Fishes of West Africa; Royal Museum for Central Africa: Tervuren, Belgium, 2003.

23. Ivanova, N.V.; Zemlak, T.S.; Hanner, R.H.; Hebert, P. Universal primer cocktails for fish DNA barcoding. Mol. Ecol. Notes 2007, 7 , 544-548. [CrossRef]

24. Tamura, K.; Peterson, D.; Peterson, N.; Stecher, G.; Nei, M.; Kumar, S. MEGA5: Molecular Evolutionary Genetics Analysis Using Maximum Likelihood, Evolutionary Distance, and Maximum Parsimony Methods. Mol. Biol. Evol. 2011, 28, 2731-2739. [CrossRef]

25. Pereira, L.H.G.; Hanner, R.; Foresti, F.; Oliveira, C. Can DNA barcoding accurately discriminate megadiverse Neotropical freshwater fish fauna? BMC Genet. 2013, 14, 20. [CrossRef]

26. Ward, R.D. DNA barcode divergence among species and genera of birds and fishes. Mol. Ecol. Resour. 2009, 9, 1077-1085. [CrossRef] 
27. Leigh, J.W.; Bryant, D. POPART: Full-feature software for haplotype network construction. Methods Ecol. Evol. 2015, 6, 1110-1116. [CrossRef]

28. Saitou, N.; Nei, M. The neighbor-joining method: A new method for reconstructing phylogenetic trees. Mol. Biol. Evol. 1987, 4, 406-425. [CrossRef] [PubMed]

29. Aquino, L.M.G.; Tango, J.M.; Canoy, R.J.C.; Fontanilla, I.K.C.; Basiao, Z.U.; Ong, P.S.; Quilang, J.P. DNA barcoding of fishes of Laguna de Bay, Philippines. Mitochondrial DNA 2011, 22, 143-153. [CrossRef]

30. Falade, M.O.; Opene, A.J.; Benson, O. DNA barcoding of Clarias gariepinus, Coptodon zillii and Sarotherodon melanotheron from Southwestern Nigeria. F1000Research 2016, 5, 1268. [CrossRef]

31. Kide, N.G.; Dunz, A.; Agnèse, J.-F.; Dilyte, J.; Pariselle, A.; Carneiro, C.; Correia, E.; Brito, J.; Yarba, L.O.; Kone, Y.; et al. Cichlids of the Banc d'Arguin National Park, Mauritania: Insight into the diversity of the genus Coptodon. J. Fish Biol. 2016, 88, 1369-1393. [CrossRef] [PubMed]

32. He, A.Y.; Tang, S.J.; Jiang, Y.T.; Li, S.F.; Wang, C.H. Complete mitochondrial genome of blackchin tilapiaSarotherodon melanotheron (Perciformes, Cichlidae). Mitochondrial DNA 2011, 22, 171-173. [CrossRef] [PubMed]

33. Falk, T.M.; Teugels, G.G.; Abban, E.K.; Villwock, W.; Renwrantz, L. Phylogeographic patterns in populations of the black-chinned tilapia complex (Teleostei, Cichlidae) from coastal areas in West Africa: Support for the refuge zone theory. Mol. Phylogenet. Evol. 2003, 27, 81-92. [CrossRef]

34. Trewavas, E. Tilapias: Taxonomy and Speciation. In Proceedings of the International Conference on the Biology and Culture of Tilapias, Bellagio, Italy, 2-5 September 1980; Pullin, R.S.V., Lowe-McConnell, R.H., Eds.; International Center for Living Aquatic Resources Management (ICLARM): Manila, Philippines, 1982; pp. 3-13.

35. Englund, R.A. The loss of native biodiversity and continuing nonindigenous species introductions in freshwater, estuarine, and wetland communities of Pearl Harbor, Oahu, Hawaiian Islands. Estuaries 2002, 25, 418-430. [CrossRef]

36. Li, S.F.; Yan, B.; Cai, W.Q.; Li, T.Y.; Jia, J.H.; Zhang, Y.H. Evaluation of growth, salt tolerance and parents' heterosis contribution in reciprocal hybrids F2 between Oreochromis niloticus and Sarotherodon melanotheron. J. Fish. China 2008, 32, 335-341. 